\title{
MEASURING CRANIOCAUDAL INSTABILITY IN STIFLE JOINTS OF DOGS USING STRESS RADIOGRAPHS
}

\author{
J. ZATLOUKAL ${ }^{1}$, A. NEČAS ${ }^{2}$, M. DVOŘÁK ${ }^{2}$ \\ ${ }^{1}$ Department of Diagnostic Imaging, Small Animal Clinic, University of Veterinary and Pharmaceutical \\ Sciences, Brno, Czech Republic \\ ${ }^{2}$ Department of Surgery and Orthopedics, Small Animal Clinic, University of Veterinary and Pharmaceutical \\ Sciences, Brno, Czech Republic
}

Received September 6, 2000

Accepted November 22, 2000

Abstract

Zatloukal J., Nečas, A., Dvořák, M: Measuring Craniocaudal Instability in Stifle Joints of Dogs Using Stress Radiographs. Acta Vet. Brno 2000, 69: 311-317.

Craniocaudal stifle joint laxity in dogs affected by various stifle disorders was determined using mediolateral X-ray projections of the stifle joint in neutral and tibial compression stress position. In all, 129 stifle joints of 80 dogs were included in the study.

Patients were classified into following groups characterised by: 1) total cranial cruciate ligament (CCL) rupture, 2) total CCL rupture and medial meniscus lesion, 3) partial CCL rupture, 4) partial CCL rupture and medial meniscus lesion, 5) clinically evident CCL rupture only, 6) normal stifle joints, 7) normal stifle joint on the contralateral joint to the one affected by the CCL rupture, 8) radiographically abnormal and clinically stable stifle contralateral to the joint affected by the CCL rupture, and 9) other stifle disorders. Index of laxity (IL) of the stifle joint giving the extent of cranial tibial displacement relative to the femur in the stress tibial compression projection expressed as percents of the femur width was computed.

Stifle joints with IL values over 25 can be supposed to be affected by CCL rupture, whereas joints with the IL value less than 15 can be considered to have an intact cranial cruciate ligament. There were significantly higher IL values in stifle joints with clinically or by arthrotomy diagnosed CCL rupture as compared to the group of healthy joints (Wilcoxon's test; $p<0.01$ and $p<0.05$, respectively in these ones with partial CCL rupture and medial meniscus damage).

Contrary to published data, we found considerably higher IL values in stifle joints with total CCL rupture as compared to those ones with partial rupture $(p<0.01)$. Significant differences in the index of laxity value were not found in stifles with other disorder than the CCL rupture as compared to the group of healthy joints. Measurement of the index of laxity is an undemanding and noninvasive technique supplementing the clinical examination and could serve as an early diagnostic method for the CCL injury.

Index of laxity, stifle joint, cranial cruciate ligament, rupture, tibial compression test

Disorders of the stifle joint in dogs are relatively frequent (Johnson et al. 1994). Craniocaudal instability of the stifle joint is mainly associated with the cranial cruciate ligament rupture (CCL). This instability is diagnosed clinically by the cranial drawer sign and tibial compression test and is mainly pathognomonic for the CCL rupture (Arnoczky 1993). It is more difficult to diagnose cases of chronic stifle joint affection with periarticular fibrosis or partial CCL rupture, when even in sedation of the patient, the clinically detectable instability is small or non-conclusive (Tarvin and Arnoczky 1981, Scavelli et al. 1990, Strøm 1990, de Rooster and van Bree 1999a). The diagnosis of the CCL rupture in these cases is based on ruling out other causes of lameness due to the stifle joint disorder. It may be necessary to directly evaluate the integrity of the cranial cruciate ligament using arthroscopy or arthrotomy (Miller and Presnell 1985). Radiographic examination of the stifle joint in neutral projections shows in cases of CCL rupture only nonspecific changes such as arthrosis and effusion in the stifle joint. It is only in exceptional

Address for correspondence:

MVDr. Josef Zatloukal

Department of Diagnostic Imaging, Small Animal Clinic

University of Veterinary and Phas, Snatical Sciences

Palackého 1-3, 612 42 Brno, Czech Republic,

Phone: +420602511428

Fax: +420541562344

http://www.vfu.cz/acta-vet/actavet.htm 
cases of CCL rupture together with avulsion fracture that this severed bone fragment can be proved radiographically (Jerome 1982; Singh et al. 1996). The cranial displacement of the proximal tibia relative to the femur (i.e., Cazieux-positive) is a specific radiographic sign for the CCL rupture. This sign, however, is evident only in a small number of CCL rupture cases (Pond and Campbell 1972; Kirby 1993). The above-mentioned cranial displacement of the proximal tibia may be set off using radiographs of the stifle joint in stress projections (Farrow 1982). As far as stress X-ray views in the diagnosis of the CCL rupture in dogs are concerned, especially the tibial stress projection is utilised because flexion of the tarsal joint creates compression forces in the stifle joint and in cases of the CCL damage it causes cranial displacement of the proximal tibia relative to the femur. This displacement is visible both in the total and partial CCL rupture. It can be evaluated by subjective or objective ways utilizing the measurement of the degree of the mentioned tibial displacement using paired mediolateral projections of the stifle joint in neutral and stress projections (de Rooster et al. 1998; de Rooster and van Bree 1999ab).

It was the aim of our study to determine the craniocaudal laxity of the stifle joint in dogs affected by various degree of stifle disorders using mediolateral radiographic projections of the stifle joint in neutral and tibial compression stress projections.

\section{Materials and Methods}

The study included a total of 129 stifle joints in 80 dogs. Stifle joints were on the basis of final diagnosis divided into following groups: 1) total CCL rupture (21 cases), 2) total CCL rupture and medial meniscus lesion (15 cases), 3) partial CCL rupture (6 cases), 4) partial CCL rupture and medial meniscus lesion (3 cases), 5) clinically evident CCL rupture only (18 cases), 6) normal stifle joints (21 cases), 7) normal stifle joint contralateral to the joint affected by the CCL rupture (17 cases), 8) radiographically abnormal and clinically stable stifle contralateral to the joint affected by the CCL rupture (9 cases), and 9) other stifle disorders ( 20 cases).

The degree of damage to the cranial cruciate ligament and lesion of the medial meniscus were in all cases classified into groups 1 to 4 examined by arthrotomy. Group 5 included cases in which we clinically found positive drawer sign and tibial compression test but the diagnosis of the CCL rupture was not proved by arthrotomy or arthroscopy (disapproval of the owner because of financial reasons, concurrent orthopedic or other problems). Group 6 of normal stifle joints included only those patients who were never lame in pelvic limbs and clinical or radiographic examination resulted in finding no abnormality of the stifle (no painful reaction on manipulation with the stifle joint, no radiographic signs of joint effusion or arthrosis). When the CCL rupture was diagnosed in one stifle joint of a patient and at the same time the contralateral joint was without signs of craniocaudal instability (negative cranial drawer test and tibial compression test), the contralateral joint was on the basis of radiographic examination included into one of the two following groups. Joints with effusion and/or arthrosis were classified as group 8 and joints without radiographic abnormalities as group 7. The last group included stifle joints affected by other disorders. There were 5 cases of septic arthritis, 9 cases of immune-mediated non-erosive arthritis and 5 cases of osteochondrosis of the stifle joint (in all these cases lesions were localized on the lateral femoral condyle) in this group.

Two mediolateral projections of the stifle joint using the technique by de Rooster et al. (1998) were made in every dog. Stifle joint radiographs in mediolateral projection were made in its neutral position (approximately $90^{\circ}$ flexion in the stifle joint). For the purpose of the study the stifle joint was radiographically examined in a second projection, i.e., in maximum flexion of the tarsal joint (tibial compression stress projection). All radiographs were taken in patients in deep sedation using the combination of medetomidin (10-20 $\mu \mathrm{g} / \mathrm{kg}$ i.v.) and butorphanol (0.2 $\mathrm{mg} / \mathrm{kg}$ i.v.) or general inhalation anesthesia.

Patient positioning for the stress projections was done every time by the same experienced radiologist. A modification of the technique by de Rooster et al. (1998) was used for the evaluation of craniocaudal instability of the stifle joint. On the mediolateral radiograph of the stifle joint (cf. Figures 1 and 2) one horizontal line (h) passing parallel to the joint surface of tibial plateau was plotted. There were two other lines plotted perpendicular to this line on the radiograph. The first one was going through the most caudal margin of the lateral condyle of the tibia (a) and the second one through the most caudal margin of the lateral condyle of the femur (b). The distance between these two vertical lines was measured. This measurement was performed in both paired projections (i.e., the neutral (cf. Figure 1) and tibial compression (cf. Figure 2) ones) and the difference between these two measurements was recorded as the relative measure of radiographic instability. Considering the size of the stifle joint, this value was divided by the diameter of the femur measured from the mediolateral radiographs just proximal to tuberositas supracondylaris lateralis and multiplied by 100 . The resulting index of radiographic laxity (IL) of the stifle joint gives the degree of cranial displacement of the tibia in the stress tibial compression projection expressed in percents of the femur diameter.

For the given measurement we did not consider the enlargement of the object due to direct contact of the stifle 
joint with the radiographic cartridge. Stifle joints in which there were marked errors of positioning such as joint rotation and non-equal degrees of flexion in the joint in neutral and tibial compression projections were excluded from the study. All measurements were twice repeated and arithmetic mean values were used for further statistical evaluation. The same experienced radiologist, who was not at the time conversant with the clinical findings, performed the measurements.

In each group of stifle joints we compared the IL values with that of healthy stifle joints. We also compared the IL value between the group of stifle joints with total CCL rupture and the group of stifle joints with total CCL rupture and concurrent medial meniscus damage. The same concerned the group of joints with partial CCL rupture. We also compared the IL value in stifle joints with the partial CCL rupture and healthy stifle joints without considering the medial meniscus damage. The group of abnormal and clinically stable joints that were contralateral to those ones with diagnosed CCL rupture was also statistically analyzed. As far as this group of joints was concerned, we compared the IL value with the group of joints affected by the total CCL rupture and the group of joints with partial CCL rupture (not regarding the medial meniscus damage). Wilcoxon's (rank) test was used to statistically analyze the data.

\section{Results}

Table 1 presents the median, minimum IL value, maximum IL value, mean and standard deviation of the IL value in individual groups of stifle joints. The index of laxity as compared to the group of healthy stifle joints was not different with statistical significancy in the group of stifle joints contralateral to the diagnosed CCL rupture (normal as well as abnormal radiographically) and the group of stifle joints affected by other disorders. On the other hand, stifle joints with clinically or by arthrotomy diagnosed CCL rupture had significantly higher

Table 1

Evaluation of the index of laxity (IL) in individual groups of stifle joints

\begin{tabular}{|c|c|c|c|c|c|c|c|c|c|}
\hline & 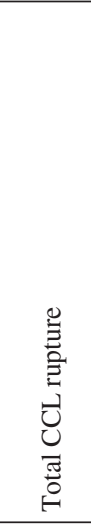 & 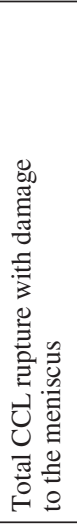 & 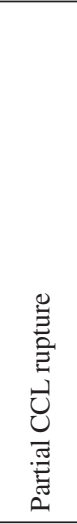 & 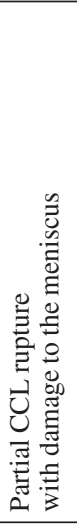 & 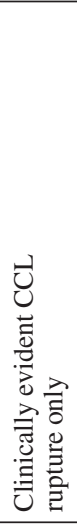 & 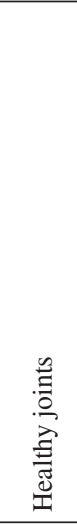 & 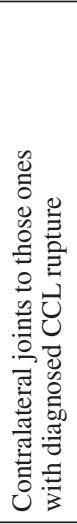 & 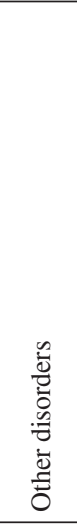 & 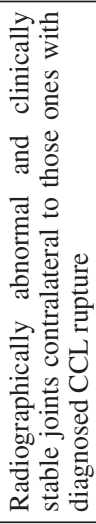 \\
\hline Numbers & 21 & 15 & 6 & 3 & 18 & 21 & 17 & 20 & 9 \\
\hline Minimum & 20.84 & 28.95 & 16.67 & 15.64 & 16.67 & 4.00 & 0 & 0 & 5.17 \\
\hline Maximum & 105.00 & 96.11 & 55.26 & 35.00 & 61.54 & 24.80 & 35.00 & 23.08 & 33.33 \\
\hline Median & 59.09 & 44.74 & 29.17 & 25.00 & 37.09 & 9.09 & 11.37 & 10.65 & 19.95 \\
\hline Mean & 55.83 & 48.73 & 31.98 & 24.55 & 38.49 & 10.73 & 12.74 & 10.62 & 19.01 \\
\hline $\begin{array}{l}\text { Standard } \\
\text { deviation }\end{array}$ & 23.91 & 20.79 & 13.91 & 10.69 & 13.05 & 6.32 & 9.84 & 7.22 & 10.85 \\
\hline $\begin{array}{l}\text { Comparison } \\
\text { with normal } \\
\text { healthy } \\
\text { stifle joints }\end{array}$ & 个个 & 个个 & 个个 & 个个 & $\uparrow$ & - & $\mathrm{N}$ & $\mathrm{N}$ & $\mathrm{N}$ \\
\hline
\end{tabular}

Explanation: $\uparrow \uparrow$ considerably higher IL value as compared to the group of healthy stifle joints $(p<0.01)$ $\uparrow$ higher IL value as compared to the group of healthy stifle joints $(p<0.05)$

$\mathrm{N}$ insignificant difference of IL value as compared to the group of healthy stifle joints 
IL values as compared to the group of healthy joints ( $p<0.01$ and $p<0.05$, respectively in those with partial CCL rupture and medial meniscus damage). These data are summarised in Table 1. We did not prove significant differences between the group of stifle joints with total/partial CCL ruptures without damage to the medial meniscus and the group of total/partial CCL ruptures with concurrent medial meniscus damage (cf. Table 1). Comparing the index of laxity in stifle joints with total CCL rupture and partial CCL rupture we found considerably higher IL values in stifle joints affected by total CCL rupture $(p<0.01)$. Radiographically abnormal and clinically stable joints contralateral to those ones with diagnosed CCL rupture were not characterized by statistically significant differences in the IL values when compared both to healthy stifle joints and stifle joints affected by partial CCL rupture.

The index of laxity smaller than 15 was found in our study only in stifle joints not affected by CCL rupture. The index of laxity over 25 was found in stifle joints with total or partial CCL rupture. The index of laxity from 15 to 25 was, however, found in all the groups of stifle joints. The index of laxity lying within this interval was found in $5.56 \%$ of cases with total CCL rupture, $55.56 \%$ of cases with partial CCL rupture, $23.81 \%$ of cases of normal stifle joints, $22.22 \%$ of cases of normal stifle joint on the contralateral joint to the joint affected by the CCL rupture, $37.50 \%$ of cases of radiographically abnormal and clinically stable stifle contralateral to the joint affected by the CCL rupture and $25 \%$ of cases of other stifle disorders. Graph 1 presents the proportion of IL values in individual stifle joint groups.

\section{Discussion}

The cranial cruciate ligament rupture in the dog is a relatively frequent orthopedic problem (Whitehair et al. 1993) and participates in more than one half of pathological disorders of the stifle joint (Johnson et al. 1994). The diagnosis of damage to the cranial cruciate ligament is mainly based on clinical examination of craniocaudal instability which may be insignificant in cases of partial CCL rupture. Scavelli et al. (1990) did not prove positive drawer sign in $48 \%$ of patients with partial CCL rupture. Arthroscopy and arthrotomy are the only really specific methods to evaluate the status of the cranial cruciate ligament.

Stress machines tried for the purpose of diagnosing the craniocaudal instability of the stifle joint in man did not reach common application both because of the high price of special instruments and low testifying value influenced by the mass of surrounding soft tissue especially in the caudal stifle joint area (Torzilli et al 1991; Torzilli et al 1984; Torzilli et al. 1981; Kennedy and Fowler 1971). Radiographic evaluation of stifle joint instability using stress projections eliminates the inaccuracy of mentioned methods because only bone structures are considered. The tibial compression projection in subjective craniocaudal instability evaluation is $100 \%$ specific and $97 \%$ sensitive as compared to the cranial drawer test which is only $86 \%$ sensitive and $98 \%$ specific (de Rooster et al. 1998). In this subjective evaluation the test was considered to be positive or negative on the basis of displacement of the proximal tibia and tuberculum intercondylaris tibiae in the stress projection as compared to their neutral projection. The position of popliteal sesamoid bones, provided they were ossified, was taken into consideration (de Rooster and van Bree 1999c).

De Rooster and van Bree (1999b) quantified the degree of craniocaudal laxity of the stifle joint in dogs on the basis of radiographs in tibial compression projections issued from two methods used in human medicine. In our study we used the method proved to be more accurate. Comparing the index of laxity between individual groups of stifle joints we found that joints with clinically or by arthrotomy diagnosed CCL ruptures had significantly higher IL values $(p<0.01$ or $p<0.05$ in stifle joints with partial CCL ruptures and medial meniscus damage) than healthy joints. On the other hand, the group of stifle joints, in which there was 
other cause of stifle disorder than the CCL rupture, did not show significant differences in the index of laxity value as compared to the group of healthy joints. These results correspond to findings of other authors (de Rooster and van Bree 1999b) and prove the fact that the cranial tibial displacement relative to the femur in the tibial compression stress projection depends only on the damage of the cranial cruciate ligament. We, like de Rooster and van Bree (1999b), did not find significancy of the IL value for the damage of the medial meniscus, even when the mean IL value was smaller in joints affected by the medial meniscus damage (both in partial and total CCL rupture joints). This finding may be caused by the fact that the medial meniscus damage is often evident in stifle joints with chronic ligament rupture which is accompanied by concurrent stabilisation of the stifle by periarticular fibrosis and thickening of the joint capsule influencing the degree of craniocaudal instability (Vasseur 1993). Contrary to published data (de Rooster and van Bree 1999b), we found considerably higher IL values in stifle joints with total CCL rupture as compared to partial CCL rupture $(p<0.01)$. These differences can be explained by small numbers of cases of partial CCL rupture both in our and the above-mentioned studies. We suppose that the partial CCL rupture leads to less craniocaudal stifle instability and thus smaller IL value. It remains questionable whether it will be possible to strictly distinguish the partial and total CCL rupture using the IL value. The answer to this question will require further detailed analyses of many more patients.

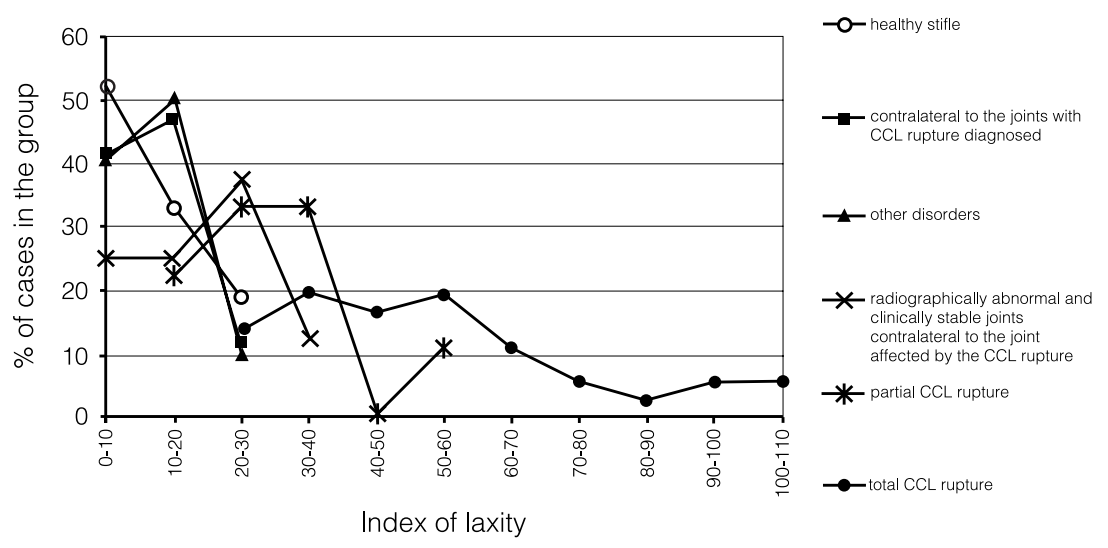

Fig. 3. Proportion of the index of laxity (IL) in individual groups of stifle joints

Though we, like de Rooster and van Bree (1999b), found statistically significant differences in the index of laxity between stifle joints with partial/total CCL ruptures and healthy joints, it was not possible to determine in individual cases based on IL value only, whether it was the cranial cruciate ligament rupture. On the basis of our results we can suppose stifle joints with IL value over 25 to be affected by the CCL rupture while stifle joints with the IL value lower than 15 may be considered to have the cranial cruciate ligament intact. Stifle joints with the index of laxity from 15 to 25 occurred both in the group of normal joints and those ones with affections of the cranial cruciate ligament (cf. Fig. 3). The index of laxity lying within this interval was found in $5.56 \%$ of cases with CCL rupture, $55.56 \%$ of cases with partial CCL rupture, $23.81 \%$ of cases of normal stifle joints, $22.22 \%$ of cases of normal stifle joint on the contralateral joint to the joint affected by the CCL rupture, $37.50 \%$ of cases of radiographically abnormal and clinically stable stifle contralateral to the joint affected by the CCL rupture and $25 \%$ of cases of other stifle 
disorders. There may be several reasons and their possible combinations. The measurement of the IL value disregarded, for example, breed and age variability of dogs. Moderate craniocaudal instability (1 to $3 \mathrm{~mm}$ ) in the drawer test may be found in young dogs with healthy joints and it is not considered to be pathologic ( V a s s e ur 1993). It will be probably obligatory to precisely position the limb for the radiography because even small rotation of the stifle or differing angles of flexion in the stifle in neutral and tibial compression projections might influence the result of IL value measurement. The proper measurement of the craniocaudal laxity is also loaded by some error originating mainly from the identification of marginal points of bones and horizontal lines plotting (de Rooster et al. 1998) especially in stifle joints with arthrosis. It is not quite clear to what extent the measurement of craniocaudal instability is influenced by periarticular fibrosis in arthrosis and joint effusion. Long-term patient monitoring will be necessary to find out whether the difference of IL value within the interval from 15 to 25 already indicates pathological changes of the cranial cruciate ligament even when the stifle joint is still clinically without abnormalities. Such considerations may be based on the finding of CCL ruptures (partial and total ones) in two stifle joints by the end of our study, which were in our study classified as normal stifle joints contralateral to joints with diagnosed CCL rupture (IL 15.63 and 17.19). The index of laxity could then serve as an early sign of the cranial cruciate ligament damage and its measurement using tibial compression projections could help in the early diagnosis of CCL rupture in dogs. In spite of these to a greater extent unanswered questions we can on the basis of our study recommend the measurement of craniocaudal instability of the stifle joint using tibial compression projections as an easy and non-invasive examination of the stifle joint supplementing the basic clinical examination.

\section{Měření kraniokaudální instability kolenního kloubu u psů ze stresových rentgenogramů}

Z mediolaterálních rtg projekcí kolenních kloubů v neutrální pozici a v tibiální kompresní stresové pozici byla stanovena kraniokaudální laxita kolenního kloubu u psů s různým postižením kolena. Do studie bylo zahrnuto celkem 129 kolenních kloubů u 80 psů.

Pacienti byli zařazeni do jedné $\mathrm{z}$ následujících skupin: 1) s totální rupturou předního zkříženého vazu (LCC), 2) s totální rupturou LCC a lézí mediálního menisku, 3) s parciální rupturou LCC, 4) s parciální rupturou LCC a poškozením mediálního menisku, 5) s pouze klinicky patrnou rupturou LCC, 6) s normálním kolenním kloubem, 7) s normálním kolenním kloubem kontralaterálním ke kloubu s rupturou LCC, 8) s rentgenologicky abnormálním, klinicky stabilním kolenem kontralaterálním ke kloubu s rupturou LCC a 9) s jiným onemocněním kolena. Byl vypočítán index laxity (IL) kolenního kloubu (vyjádřený $\mathrm{v}$ procentech šířky femuru) udávající míru kraniální dislokace tibie vzhledem $\mathrm{k}$ femuru při stresové tibiální kompresní projekci.

U kolenních kloubů s IL > 25 lze předpokládat rupturu LCC, zatímco kolenní klouby s IL $<15$ lze považovat za klouby s intaktním předním zkříženým vazem. Kolenní klouby s klinicky či artrotomicky prokázanou rupturou LCC měly signifikantně vyšší IL než zdravé klouby (Wilcoxonův test; $p<0,01$, respektive $p<0,05$ u kolenních kloubů s parciální rupturou LCC a poškozením mediálního menisku).

Na rozdíl od dosud publikovaných údajů jsme zjistili výrazně vyšší IL u kolenních kloubů $\mathrm{s}$ totální rupturou LCC $\mathrm{v}$ porovnání $\mathrm{s}$ př́ípady parciální ruptury vazu $(p<0,01)$. U kolenních kloubů postižených jiným onemocněním než rupturou LCC jsme při porovnání s klouby zdravými neprokázali rozdíl v indexu laxity. Měření indexu laxity kolenního kloubu je nenáročná a neinvazivní technika doplňující klinické vyšetření, která by se mohla stát časnou diagnostickou metodou při poškození LCC. 


\section{Acknowledgements}

This work was supported by the Ministry of Education, Youth and Sports of the Czech Republic (Research Project No. 161700002).

\section{References}

ARNOCZKY, S. P. 1993: Pathomechanics of cruciate ligament and meniscal injuries. In: BOJRAB, M. J.: Disease mechanisms in small animal surgery. $2^{\text {nd }}$ ed. Lea \& Febiger, Philadelphia, pp. $764-776$

DE ROOSTER, H., VAN BREE, H. 1999a: Use of compression stress radiography for detection of partial tears of the canine cranial cruciate ligament. J. Small Anim. Pract. 40: 573 - 576

DE ROOSTER, H., VAN BREE, H. 1999b: Radiographic measurement of craniocaudal instability in stifle joint of clinically normal dogs and dogs with injury of cranial cruciate ligament. Am. J. Vet. Res. 60: 1567 - 1570

DE ROOSTER, H., VAN BREE, H. 1999c: Popliteal sesamoid displacement associated with cruciate rupture in the dog. J. Small Anim. Pract. 40: 316 - 318

DE ROOSTER, H., VAN RYSSEN, B., VAN BREE, H. 1998: Diagnosis of cranial cruciate ligament injury in dogs by tibial compression radiography. Vet. Rec. 142: 336 - 368

FARROW, C. S. 1982: Stress radiography: Applications in small animal practice. . J. Am. Vet. Med. Assoc. 181: $777-784$

JEROME, D. R. 1982: Cruciate ligament avulsion injury in dogs. J. Am. Anim. Hosp. Assoc. 18: 257 - 264

JOHNSON, J. A., AUSTIN, C., BREUR, G. J. 1994: Incidence of canine appendicular musculoskeletal disorders in 16 veterinary teaching hospitals from 1980 through 1989. Vet. Comp. Orthop. Trauma 7: 56 - 69

KENNEDY, J. C., FOWLER, P. J. 1971: Medial and anterior instability of the knee. An anatomical and clinical study using stress machines. J. Bone Joint Surg. Am. 53: 1257 - 1270

KIRBY, B. M. 1993: 1: Decision-making in cranial cruciate ligament ruptures.Vet. Clin. North Am. Small Anim. Pract. 23: 797 - 819

MILLER, C. W., PRESNELL, K. R. 1985: Examination of the canine stifle: arthroscopy versus arthrotomy. J. Am. Anim. Hosp. Assoc. 21: 623 - 629

POND, M. J., CAMPBELL, J. 1972: The canine stifle joint. I. Rupture of the anterior cruciate ligament. An assessment of conservative and surgical treatment. J. Small Anim. Pract. 13: 1 - 10

SCAVELLI, T. D., SCHRADER, S. C., MATTHIESEN, D. T., SKORUP, D. E. 1990: Partial rupture of the cranial cruciate ligament of the stifle in dogs: 25 cases (1982-1988). J. Am. Vet. Med. Assoc. 196: 1135 - 1138

SINGH, B., SUKHIANI, H. R., TANO, C. A., DOBSON, H., MILLER, C. W. 1996: Cranial cruciate ligament avulsion in skeletally immature Saint Bernard dog. Vet. Comp. Orthop. Trauma 9: 190 - 192

STRIM, H. 1990: Partial rupture of the cranial cruciate ligament in dogs. J. Small Anim. Pract. $31: 137$ - 140

TARVIN, G. B., ARNOCZKY, S. P. 1981: Incomplete rupture of the cranial cruciate ligament in a dog. Vet. Surg. 10: $94-95$

TORZILLI, P. A., GREENBERG, R. L., HOOD, R. W., PAVLOV, H., INSALL, J. N. 1984: Measurement of anterior-posterior motion of the knee in injured patients using a biomechanical stress technique. J. Bone Joint Surg. Am. 66: $1438-1442$

TORZILLI, P. A., GREENBERG, R. L., INSALL, J. 1981: An in vivo biomechanical evaluation of anteriorposterior motion of the knee. Roentgenographic measurement technique, stress machine, and stable population. J. Bone Joint Surg. Am. 63: 960 - 968

TORZILLI, P. A., PANARIELlO, R. A., FORBES, A., SANTNER, T. J., WARREN, R. F. 1991: Measurement reproducibility of two commercial knee test devices. J. Orthop. Res. 9: 730 - 737

VASSEUR, P. B. 1993: Stifle joint. In: SLATTER, D.: Textbook of Small Animal Surgery, 2nd ed., W. B. Saunders, Philadelphia, pp. 1817 - 1865

WHITEHAIR, J. G., VASSEUR, P. B., WILLITS, N. H. 1993: Epidemiology of cranial cruciate ligament rupture in dogs. J. Am. Vet. Med. Assoc. 203: 1016 - 1019 
Plate III

Zatloukal J. et al.: Measuring ... pp. 311-317

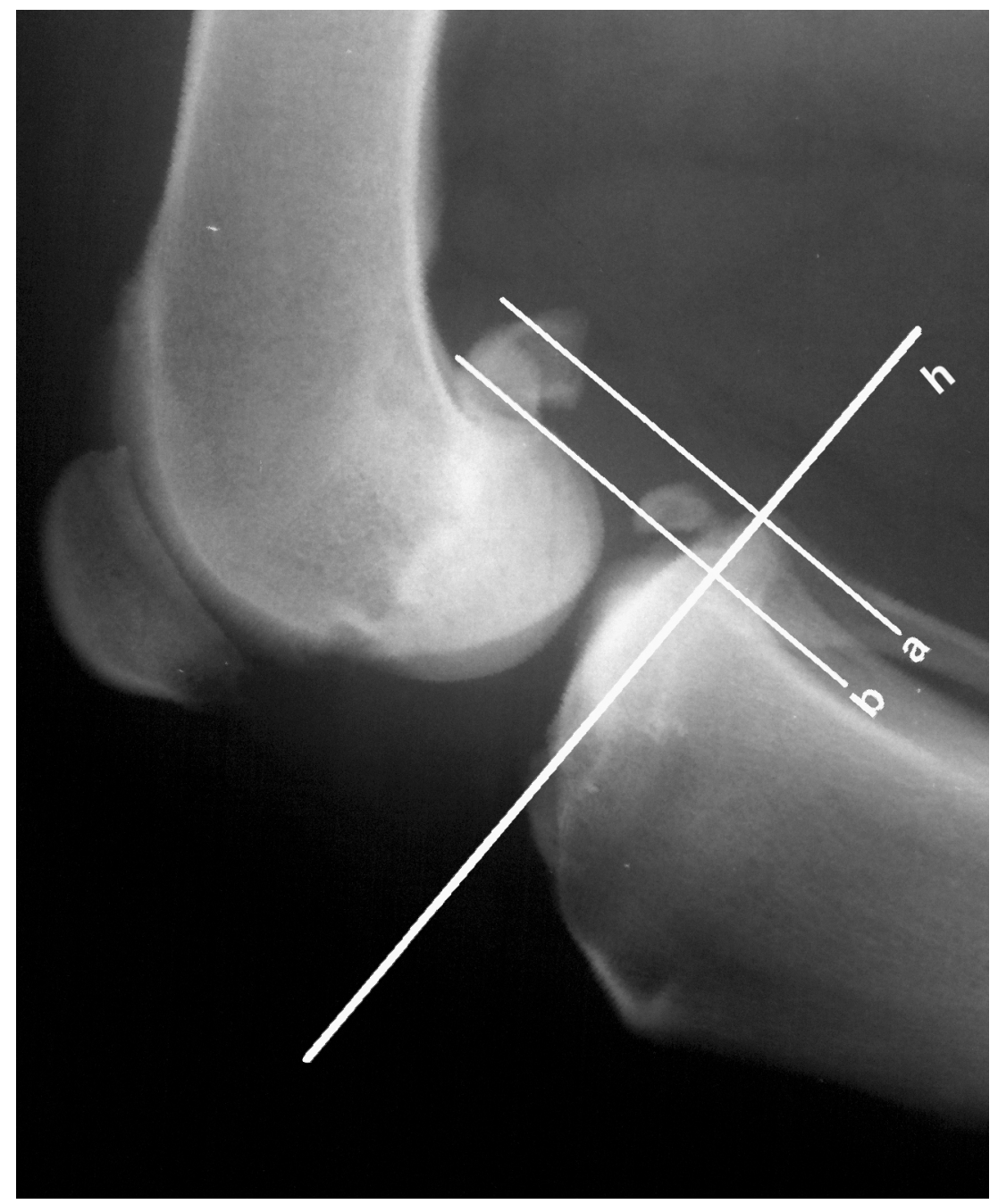

Fig. 1: Mediolateral radiograph of the stifle joint in the neutral position. There were horizontal line (h) (passing parallel to the joint surface of tibial plateau) and two other lines (perpendicular to this line) plotted. The first one was drawn through the most caudal margin of the lateral condyle of the tibia (a) and the second one through the most caudal margin of the lateral condyle of the femur (b). The distance between these two vertical lines was measured. 
Plate IV

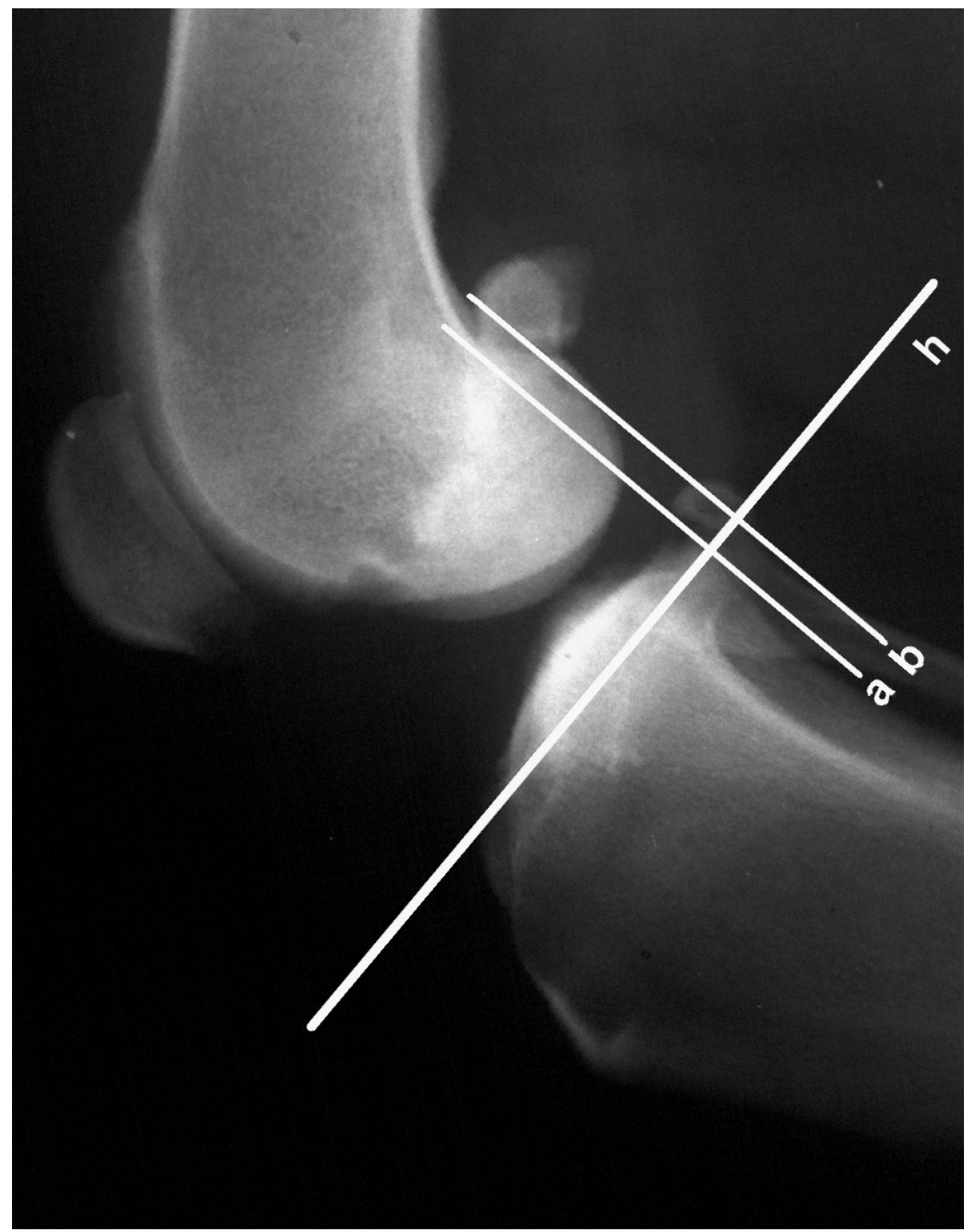

Fig. 2: Mediolateral view of the stifle joint under tibial compression test in the same patient as in Fig. 1. The horizontal (h) and two vertical (a, b) lines are also plotted. 